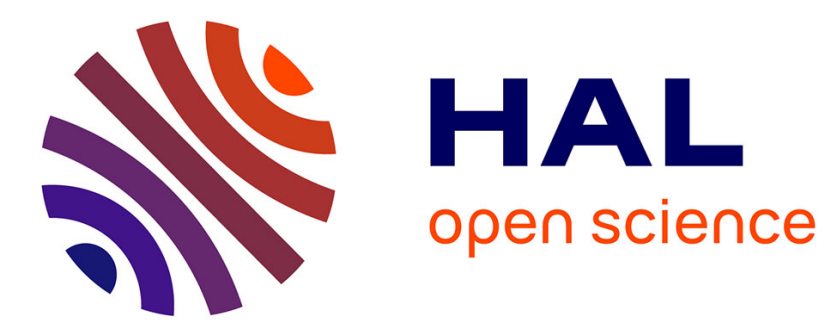

\title{
Isotopic Evidence for Multiple Recycled Sulfur Reservoirs in the Mangaia Mantle Plume
}

J. W. Dottin, J. Labidi, M. G. Jackson, J. Woodhead, J. Farquhar

\section{To cite this version:}

J. W. Dottin, J. Labidi, M. G. Jackson, J. Woodhead, J. Farquhar. Isotopic Evidence for Multiple Recycled Sulfur Reservoirs in the Mangaia Mantle Plume. Geochemistry, Geophysics, Geosystems, 2020, 21, p. 54-71. 10.1029/2020GC009081 . insu-03584471

\section{HAL Id: insu-03584471 \\ https://hal-insu.archives-ouvertes.fr/insu-03584471}

Submitted on 22 Feb 2022

HAL is a multi-disciplinary open access archive for the deposit and dissemination of scientific research documents, whether they are published or not. The documents may come from teaching and research institutions in France or abroad, or from public or private research centers.
L'archive ouverte pluridisciplinaire HAL, est destinée au dépôt et à la diffusion de documents scientifiques de niveau recherche, publiés ou non, émanant des établissements d'enseignement et de recherche français ou étrangers, des laboratoires publics ou privés.

$$
\text { Copyright }
$$




\section{Geochemistry, Geophysics, Geosystems}

\author{
RESEARCH ARTICLE \\ 10.1029/2020GC009081 \\ Key Points: \\ - We report bulk S-isotope \\ compositions of sulfide in melt \\ inclusions of olivines and pyroxenes \\ from Mangaia \\ - Isotopic disequilibrium in a single \\ sample records a process of trapping \\ various compositions during magma \\ mixing \\ - Data collected identify a new, \\ potentially young, recycled \\ component with negative $\delta^{34} \mathrm{~S}$ and \\ slightly positive $\Delta^{33} \mathrm{~S}$ in HIMU \\ source
}

Supporting Information:

- Supporting Information S1

Correspondence to:

J. W. Dottin III,

jdottin@umd.edu

\section{Citation:}

Dottin, J. W. III, Labidi, J., Jackson, M. G., Woodhead, J., \& Farquhar, J. (2020). Isotopic evidence for multiple recycled sulfur reservoirs in the Mangaia mantle plume. Geochemistry, Geophysics, Geosystems, 21, e2020GC009081. https://doi.org/10.1029/2020GC009081

Received 3 APR 2020 Accepted 18 SEP 2020 Accepted article online 23 SEP 2020

(C)2020. American Geophysical Union. All Rights Reserved.

\section{Isotopic Evidence for Multiple Recycled Sulfur Reservoirs in the Mangaia Mantle Plume}

\author{
J. W. Dottin III ${ }^{1}$ iD, J. Labidi ${ }^{2}$ iD, M. G. Jackson ${ }^{3}$ iD, J. Woodhead ${ }^{4}$ iD, and J. Farquhar FiD $^{1,5}$ \\ ${ }^{1}$ Department of Geology, University of Maryland, College Park, MD, USA, ${ }^{2}$ Institut de Physique du Globe de Paris, CNRS, \\ Université de Paris, Paris, France, ${ }^{3}$ Department of Earth Science, University of California, Santa Barbara, CA, USA, \\ ${ }^{4}$ School of Earth Sciences, University of Melbourne, Parkville, Victoria, Australia, ${ }^{5}$ Earth System Science Interdisciplinary \\ Center, College Park, MD, USA
}

\begin{abstract}
Mangaia, an ocean island in the Cook-Austral volcanic chain, is the type locality for the HIMU mantle reservoir and has also been shown to exhibit evidence for recycled sulfur with anomalous $\delta^{34} \mathrm{~S}$ and $\Delta^{33} \mathrm{~S}$ that has been attributed an Archean origin. Here we report bulk S-isotope data from sulfide inclusions in olivine and pyroxene phenocrysts from one of the previously analyzed and four additional Mangaia basalts to further test for the prevalence of anomalous S in the HIMU mantle source feeding Mangaia. We document compositions that range from $-5.13 \%$ o to $+0.21 \%$ o $( \pm 0.32 \sigma),+0.006 \%$ o to $+0.049 \%$ o $( \pm 0.0162 \sigma),-0.81 \%$ o to $+0.69 \%$ o $( \pm 0.32 \sigma)$ for $\delta^{34} S, \Delta^{33} S$, and $\Delta^{36} \mathrm{~S}$, respectively. These data extend the range of measured compositions and suggest S-isotope heterogeneity in the HIMU mantle source at Mangaia. We show that S-isotope compositions of bulk sulfide in olivine is not in isotopic equilibrium with bulk sulfide in pyroxene from the same samples and that samples from a confined area (M4, M10, M12, and M13) in the northern central part of the island show a distinct covariation for $\delta^{34} \mathrm{~S}$ and $\Delta^{33} \mathrm{~S}$. This isotopic variation (forming an array) suggests mixing of sulfur from two sources that were captured at different stages of crystallization by phenocrysts in the Mangaia HIMU sulfur endmember.
\end{abstract}

Plain Language Summary The sulfur isotope composition of the mantle is heterogenous from crust formation and recycling continental and oceanic crust. Basalts, from an intraplate volcanic hotspot volcano in the Pacific Ocean, Mangaia, show isotopic evidence for hosting Archean-related sulfur that is sourced from a recycled oceanic crustal component. The prevalence of this Archean-related sulfur in the plume source that feeds Mangaia is not well constrained. In this work, we present sulfur isotope data on sulfur from minerals that crystallized deep in the magma chamber and identify a new, potentially younger, recycled sulfur source that demonstrates the diversity of materials mixing in the magma chamber prior to eruption.

\section{Introduction}

Covariations in the radiogenic isotope signatures of strontium, neodymium, and lead seen in various Mid-Ocean Ridge Basalts (MORB) and Ocean Island Basalts (OIB) have been used to identify distinct compositional reservoirs that exist in the mantle as a result of melt removal and recycling of oceanic and continental crust. These reservoirs have been termed Depleted MORB Mantle (DMM), Enriched Mantle I and II (EM I, EM II), and HIMU (high $\mu={ }^{238} \mathrm{U} /{ }^{204} \mathrm{~Pb}$ ). Depleted MORB mantle is characterized as having relatively low ${ }^{206,207,208} \mathrm{~Pb} /{ }^{204} \mathrm{~Pb}$ and ${ }^{87} \mathrm{Sr} /{ }^{86} \mathrm{Sr}$ but high ${ }^{143} \mathrm{Nd} /{ }^{144} \mathrm{Nd}$ and argued to have formed from the process of melt removal during crust formation (Salters \& Stracke, 2004; Workman \& Hart, 2005). HIMU is characterized by high ${ }^{206,208} \mathrm{~Pb} /{ }^{204} \mathrm{~Pb}$ (and variable ${ }^{207} \mathrm{~Pb} /{ }^{204} \mathrm{~Pb}$ ), low ${ }^{87} \mathrm{Sr} /{ }^{86} \mathrm{Sr}$, and intermediate ${ }^{143} \mathrm{Nd} /{ }^{144} \mathrm{Nd}$. The HIMU reservoir is thought to have formed from the recycling of oceanic crust that experienced $\mathrm{Pb}$ loss from sulfides during subduction followed by the ingrowth of radiogenic $\mathrm{Pb}$ due to a high ${ }^{238} \mathrm{U} /{ }^{204} \mathrm{~Pb}$ ("high $\mu$ ") time integrated ratio (e.g., Chauvel et al., 1992; Kelley et al., 2005) with a wide range of proposed formation ages of 550 Ma to 3.0 Ga (Hauri \& Hart, 1993; Mazza et al., 2019; Nebel et al., 2013; Thirlwall, 1997).

Mangaia, located in the Cook-Austral volcanic chain, is the type locality for the HIMU mantle reservoir that, together with Bermuda, preserve the highest reported radiogenic ${ }^{206} \mathrm{~Pb} /{ }^{204} \mathrm{~Pb}$ isotope compositions of any OIB locality suggesting an old and recycled mantle source (Hauri \& Hart, 1993; Mazza et al., 2019; Woodhead, 1996). Jackson and Dasgupta (2008) and Cabral et al. (2014) argue that HIMU basalts are 
associated with a carbonated mafic source on the basis of major element characteristics $\left(\right.$ low $\mathrm{SiO}_{2}$ and high $\mathrm{CaO} / \mathrm{Al}_{2} \mathrm{O}_{3}$ ) and elevated volatile contents of $\mathrm{CO}_{2}$. Weiss et al. (2016) suggest that the HIMU mantle source of Mangaia was metasomatized by carbonatitic fluids and imply a connection to recycling processes. The sulfur isotope composition of sulfides in sulfide inclusions trapped in magmatic olivine from Mangaia basalts has been measured in situ using secondary ion mass spectrometry (SIMS) and also using conventional bulk isotope methods (Cabral et al., 2013). The $\delta^{34}$ S values reported from Mangaia ( - 17\% to -3\%o) are depleted in heavy isotopes compared to bulk sulfur isotope measurements of MORB (Mid Ocean Ridge Basalt) glasses (average $\delta^{34}$ S of Pacific-Antarctic basalts $=-0.89 \pm 0.11(1 \sigma)$, Labidi et al., 2014) and additionally show small but significant negative $\Delta^{33} \mathrm{~S}$ in two samples by Secondary Ion Mass Spectrometry (SIMS), down to $-0.24 \pm 0.15 \%$ o $(2 \sigma)$ (weighted average $=-0.25 \pm 0.07 \%$ o, $2 \sigma$ ) and $-0.35 \pm 0.23 \%$ (weighted average $=-0.34 \pm 0.08 \%$ ) in MGA-B-25 and MGA-B-47, respectively. Taken together, the data collected via SIMS and conventional bulk S-isotope measurements reveal compositions that are consistent with a subducted component in the source of Mangaia melts that hosts Archean sulfur that experienced mass-independent fractionation (Cabral et al., 2013). What remains unanswered is whether anomalous Archean S is common in the HIMU mantle reservoir sampled by Mangaia or whether other Mangaia basalts contain what might be considered more typical mass-dependent sulfur.

Here, we present bulk S-isotope compositions $\left(\delta^{34} \mathrm{~S}, \Delta^{33} \mathrm{~S}\right.$, and $\left.\Delta^{36} \mathrm{~S}\right)$ of sulfide inclusions within magmatic olivine and clinopyroxene phenocrysts from five Mangaia samples. These olivine and clinopyroxene phenocrysts trap sulfide inclusions during their growth at depth in the magma chamber and, like melt inclusions (e.g., Sobolev \& Shimizu, 1993), they may shed light on melt mixing of diverse sources. Our data provide new constraints on the various recycled components that dominates HIMU mantle melts feeding lavas at Mangaia.

\section{Samples and Methods}

We present new multiple sulfur isotope data on five basaltic samples from Mangaia: MGA-B-25, M4, M10, M12, and M13. Samples are from a road cut along the northeast side of the island (MGA-B-25) and from Vau Roa stream Valley (M4, M10, M12, and M13). Samples previously analyzed (Cabral et al., 2013) using SIMS and discussed in this manuscript are from a road cut adjacent to a stream north of Tamarua village on the south side of the island (MGA-B-47) and a small outcrop revealed by a road cut near a stream on the south side of the island (MG1001B). The work by Cabral et al. (2013) also presents a bulk sulfide measurement from an olivine separate of MGA-B-47. Further, note that MGA-B-25 was analyzed in Cabral et al. (2013) but only using SIMS methods. We analyzed newly prepared aliquots of minerals from MGA-B-25, while M4, M10, M12, and M13 $(n=4)$ are samples that have not previously been analyzed for sulfur isotopes. With these new measurements we are able to (1) test for S-isotope heterogeneity at different locations on the island (possibly related to separate flows) and (2) evaluate the prevalence of negative $\Delta^{33} \mathrm{~S}$ in MGA-B-25 and Mangaia basalts generally.

\subsection{Acid Digestion}

All samples are olivine and clinopyroxene phenocryst separates that were hand-picked and cleaned by sonication in preparation for S-isotope analyses. Crushed and weighed $\mathrm{Ol}$ and Px mineral separates were placed into Teflon reaction vessels for hydrofluoric acid digestion using methods developed by Labidi et al. (2012) for the liberation of sulfide from silicates. Note that these methods have demonstrated the ability to digest and consistently receive $100 \% \pm 5 \%$ of $S$ as sulfide powders as well as sulfides dissolved in silicate melts (Labidi et al., 2012). Sulfides were extracted in this study, as the method used here only extracts sulfur of reduced valence, leaving behind sulfate if present in the samples. The digestion apparatus was first purged for $\sim 15$ min with $\mathrm{N}_{2}$. After purging, the samples were acidified and digested in a heated solution $\left(70-80^{\circ} \mathrm{C}\right)$ of 3.2 $\mathrm{M} \mathrm{CrCl}_{2}, 12 \mathrm{M} \mathrm{HCl}$, and $29 \mathrm{M} \mathrm{HF}$ in the amounts of 10,5 , and $5 \mathrm{ml}$, respectively. During this digestion, sulfide was released as $\mathrm{H}_{2} \mathrm{~S}$, bubbled ( 3-5 bubbles every $\left.\sim 1-2 \mathrm{~s}\right)$ through a water trap to remove acid vapors, before being bubbled and trapped in weakly acidic $\mathrm{AgNO}_{3}$ where $\mathrm{S}$ is precipitated as $\mathrm{Ag}_{2} \mathrm{~S}$. $\mathrm{The} \mathrm{Ag}_{2} \mathrm{~S}$ was centrifuged and rinsed three times with Milli-Q water. After rinsing, the $\mathrm{Ag}_{2} \mathrm{~S}$ was dried at $\sim 70^{\circ} \mathrm{C}$ and subsequently weighed to determine sulfur concentration. 


\subsection{Fluorination}

The weighed $\mathrm{Ag}_{2} \mathrm{~S}$ was wrapped in foil and placed into nickel reaction tubes three to five times excess $\mathrm{F}_{2}$. Reactions between $\mathrm{Ag}_{2} \mathrm{~S}$ and $\mathrm{F}_{2}$ occurred at $\sim 250^{\circ} \mathrm{C}$ for at least $12 \mathrm{hr}$. The product $\mathrm{SF}_{6}$ was separated from residual $\mathrm{F}_{2}$ by freezing into a liquid-nitrogen-cooled trap. Residual $\mathrm{F}_{2}$ was passivated through a reaction with heated $\left(\sim 110^{\circ} \mathrm{C}\right) \mathrm{KBr}$ salt. After all fluorine was passivated, the liquid nitrogen trap was replaced by an ethanol slush $\left(\sim-108^{\circ} \mathrm{C}\right.$ to $\left.-115^{\circ} \mathrm{C}\right)$ to retain cocondensed $\mathrm{HF}$, and the $\mathrm{SF}_{6}$ was sublimated into a separate liquidnitrogen-cooled trap, from which it was injected into a gas chromatograph (GC) with a 1/8-inch diameter, 6foot long Haysep- $\mathrm{Q}^{\mathrm{TM}} \mathrm{GC}$ column and a $5 \mathrm{~A}$ GC column using a helium flow rate of $20 \mathrm{ml} / \mathrm{min}$. SF 6 was monitored while passing through the GC and captured in liquid nitrogen cooled metal coils. Once captured, the $\mathrm{SF}_{6}$ was thawed to determine procedural yields as pressure and, lastly, stored in individual glass manifolds.

\subsection{Mass Spectrometry}

Isotopic variations of the four stable isotopes of sulfur $\left({ }^{32} \mathrm{~S}[95.2 \%],{ }^{33} \mathrm{~S}[0.75 \%],{ }^{34} \mathrm{~S}[4.25 \%]\right.$, and $\left.{ }^{36} \mathrm{~S}[0.02 \%]\right)$ were determined using gas source mass spectrometry of purified $\mathrm{SF}_{6}$. Measurements were made by monitoring $\mathrm{SF}_{5}{ }^{+}$ion beams at $\mathrm{m} / \mathrm{z}$ of $127,128,129$, and 131 of the purified $\mathrm{SF}_{6}$. Each sample underwent three measurements that consists of eight 26-s cycles measuring the sample and the reference gas. Data are reported in per mil using the following notation:

$$
\begin{aligned}
& \delta^{33} \mathrm{~S}=\left[\left(\left({ }^{33} \mathrm{~S} /{ }^{32} \mathrm{~S}\right)_{\text {sample }} /\left({ }^{33} \mathrm{~S} /{ }^{32} \mathrm{~S}\right)_{\mathrm{CDT}}\right)-1\right] \\
& \delta^{34} \mathrm{~S}=\left[\left(\left({ }^{34} \mathrm{~S} /{ }^{32} \mathrm{~S}\right)_{\text {sample }} /\left({ }^{34} \mathrm{~S} /{ }^{32} \mathrm{~S}\right)_{\mathrm{CDT}}\right)-1\right] \\
& \delta^{36} \mathrm{~S}=\left[\left(\left({ }^{36} \mathrm{~S} /{ }^{32} \mathrm{~S}\right)_{\text {sample }} /\left({ }^{36} \mathrm{~S} /{ }^{32} \mathrm{~S}\right)_{\mathrm{CDT}}\right)-1\right] \\
& \Delta^{33} \mathrm{~S}=\left[\left(\left({ }^{33} \mathrm{~S} /{ }^{32} \mathrm{~S}\right)_{\text {sample }} /\left({ }^{33} \mathrm{~S} /{ }^{32} \mathrm{~S}\right)_{\mathrm{CDT}}\right)-\left(\left({ }^{34} \mathrm{~S} /{ }^{32} \mathrm{~S}\right)_{\text {sample }} /\left({ }^{34} \mathrm{~S} /{ }^{32} \mathrm{~S}\right)_{\mathrm{CDT}}\right)^{0.515}\right] \\
& \Delta^{36} \mathrm{~S}=\left[\left(\left({ }^{36} \mathrm{~S} /{ }^{32} \mathrm{~S}\right)_{\text {sample }} /\left({ }^{36} \mathrm{~S} /{ }^{32} \mathrm{~S}\right)_{\mathrm{CDT}}\right)-\left(\left({ }^{34} \mathrm{~S} /{ }^{32} \mathrm{~S}\right)_{\text {sample }} /\left({ }^{34} \mathrm{~S} /{ }^{32} \mathrm{~S}\right)_{\mathrm{CDT}}\right)^{1.9}\right]
\end{aligned}
$$

Analyses are normalized to analyses of Canyon Diablo Troilite on a scale that place IAEA-S1 at a composition of $\delta^{34} \mathrm{~S}=-0.401, \Delta^{33} \mathrm{~S}=0.116$, and $\Delta^{36} \mathrm{~S}=-0.796$ (Antonelli et al., 2014). For normalization, raw delta values from sample analysis are converted to ratios and normalized to the isotope ratio associated with measurements of CDT (Antonelli et al., 2014). $\Delta^{33} \mathrm{~S}$ and $\Delta^{36} \mathrm{~S}$ are calculated from the CDT normalized delta values. Uncertainties on measurements are estimated from the long-term reproducibility on measurements (including wet chemistry, fluorination, and mass spectrometry) of standard materials and are $0.3,0.016$, and $0.3(2 \sigma)$ for $\delta^{34} \mathrm{~S}, \Delta^{33} \mathrm{~S}$, and $\Delta^{36} \mathrm{~S}$, respectively. As a test of our methods and uncertainty, we have analyzed MORB glasses that were previously analyzed in Labidi et al., (2014), namely, PAC2 DR 32-1G, PAC2 DR 06-6G, and PAC1 CU 03-3G, and one MORB glass that is not reported, PAC2 DR 20-04 (see supporting information Table S1). When a small difference in the calibration between the two labs (CDT here vs. a V-CDT calibration described in Labidi et al., 2014) are taken into account, the data are reproducible and within uncertainty of measurements between both labs. The values of CDT normalized to IAEA S-1 in the two studies are $\delta^{34} \mathrm{~S}=-0.401 \pm 0.15 \%$, $\Delta^{33} \mathrm{~S}=+0.116 \pm 0.008 \%$, and $\Delta^{36} \mathrm{~S}=-0.796 \pm 0.080 \%$ o for UMD and $\delta^{34} \mathrm{~S}_{(\mathrm{V} \text {-CDT })}=-0.14 \pm 0.52, \Delta^{33} \mathrm{~S}=+0.106 \pm 0.008$, and $\Delta^{36} \mathrm{~S}=-0.782 \pm 0.140$ for Labidi et al. (2014) (all 2SD).

\section{Results}

Bulk sulfur isotope compositions of sulfide minerals hosted in olivine and pyroxene mineral separates from Mangaia basalts are reported in Table 1 and illustrated in Figures 1 and 2. We extracted $0.54 \mathrm{mg}$ to $1.57 \mathrm{mg}$ of $\mathrm{Ag}_{2} \mathrm{~S}$ from 300 to $400 \mathrm{mg}$ of sample resulting in sulfur concentrations that range from 96 to $333 \mathrm{ppm}$. S concentration in $\mathrm{Ol}$ and $\mathrm{Px}$ from the same sample does not match and shows no systematic $\mathrm{S}$ concentration in olivine versus pyroxene separates (Table 1).

The $\delta^{34} \mathrm{~S}$ compositions measured range from $-5.1 \%$ o to $+0.2 \%$ o $( \pm 0.32 \sigma)$. Sulfide minerals hosted in olivine are not in isotopic equilibrium with sulfide minerals from pyroxene in the same sample showing $-4.0 \%$ and 
Table 1

S-isotope Compositions of Bulk Sulfide in Ol and Px Separates From Mangaia Basalts

\begin{tabular}{|c|c|c|c|c|c|c|c|c|c|c|}
\hline Sample & Rock type & $\mathrm{S}(\mathrm{ppm})$ & $\delta^{34} S$ & $\Delta^{33} S$ & $\Delta^{36} S$ & ${ }^{206} \mathrm{~Pb} /{ }^{204} \mathrm{~Pb}$ & ${ }^{207} \mathrm{~Pb} /{ }^{204} \mathrm{~Pb}$ & ${ }^{208} \mathrm{~Pb} /{ }^{204} \mathrm{~Pb}$ & Latitude & Longitude \\
\hline MGA-B-25 Px & Ankaramite & 290 & -5.1 & 0.028 & 0.0 & 21.678 & 15.807 & 40.512 & -21.9133 & -157.9144 \\
\hline MGA-B-25 Ol & Ankaramite & 333 & -4.0 & 0.016 & -0.3 & 21.678 & 15.807 & 40.512 & -21.9133 & -157.9144 \\
\hline M4 Px & Ankaramite & 185 & -1.2 & 0.026 & -0.1 & 21.668 & 15.828 & 40.565 & -21.93 & -157.93 \\
\hline M10 PX & Ankaramite & 112 & -0.8 & 0.009 & -0.2 & 21.718 & 15.837 & 40.583 & -21.93 & -157.93 \\
\hline M10 OL & Ankaramite & 161 & -0.3 & 0.008 & -0.2 & 21.718 & 15.837 & 40.583 & -21.93 & -157.93 \\
\hline M12 PX & Ankaramite & 127 & -1.6 & 0.030 & -0.2 & 21.708 & 15.831 & 40.561 & -21.93 & -157.93 \\
\hline M12 OL & Ankaramite & 322 & -2.3 & 0.035 & 0.7 & 21.708 & 15.831 & 40.561 & -21.93 & -157.93 \\
\hline M13 PX & Ankaramite & 238 & 0.2 & 0.006 & 0.0 & 21.666 & 15.817 & 40.539 & -21.93 & -157.93 \\
\hline M13 OL & Ankaramite & 96 & -2.1 & 0.049 & 0.5 & 21.666 & 15.817 & 40.539 & -21.93 & -157.93 \\
\hline MGA-B- $47^{\mathrm{a}}$ & Pictrite & & -3.28 & -0.13 & & 21.784 & 15.813 & 40.734 & -21.9379 & -157.9234 \\
\hline
\end{tabular}

Note. Data compilation of S-isotope and radiogenic $\mathrm{Pb}$ isotope compositions presented.

${ }^{\text {a} S-i s o t o p e ~ d a t a ~ f r o m ~ C a b r a l ~ e t ~ a l . ~(2013) . ~ R a d i o g e n i c ~ P b ~ f o r ~ M 4-M 13 ~ f r o m ~ W o o d h e a d ~(1996) . ~ R a d i o g e n i c ~ P b ~ d a t a ~ f o r ~ M G A-B-25 ~ a n d ~ M G A-B-47 ~ f r o m ~ H a u r i ~ a n d ~}$ Hart (1993). Estimated coordinates are sourced from the GeoRoc database. Rock characterization sourced from Woodhead (1996) and Saal et al. (1998).

$-5.1 \%$ for MGA-B-25 Ol and MGA-B-25 Px, respectively, $-0.3 \%$ and $-0.9 \%$ for M10 Ol and M10 Px, respectively, $-2.3 \%$ and $-1.6 \%$ for $\mathrm{M} 12 \mathrm{Ol}$ and $\mathrm{M} 12 \mathrm{Px}$, respectively and $-2.1 \%$ and $0.2 \%$ M $13 \mathrm{Ol}$ and M13 Px, respectively (Figure S3). This reflects remarkable intrasample (olivine vs. pyroxene in the same lava) and intersample (olivines and pyroxenes from different samples) $\delta^{34} \mathrm{~S}$ variability in Mangaia lavas. However, there is no relationship between the magnitude of the $\delta^{34} \mathrm{~S}$ value and type of mineral separate. There is also no systematic fractionation among the mineral separates from the same sample.

The $\Delta^{33} \mathrm{~S}$ and $\Delta^{36} \mathrm{~S}$ range from $+0.002 \%$ o to $+0.049 \%$ and $-0.81 \%$ o to $+0.69 \%$, respectively. $\Delta^{33} \mathrm{~S}$ values of sulfide in $\mathrm{Ol}$ and $\mathrm{Px}$ from the samples measured are similar with exception of one sample (M13) showing $\Delta^{33} \mathrm{~S}=+0.049 \%$ and $+0.006 \%$ for $\mathrm{Ol}$ and $\mathrm{Px}$, respectively. Similarly, $\Delta^{36} \mathrm{~S}$ values are similar for sulfides in pyroxene and olivine, with the exception of M12 showing $\Delta^{36} \mathrm{~S}=+0.7 \%$ o and $-0.3 \%$ o for Ol and Px, respectively. A subset of samples (M4, M10, M12, and M13) yield a rough negative correlation between $\delta^{34} \mathrm{~S}$ and $\Delta^{33} \mathrm{~S}$ (Figure 1). With the exception of two data points (M13 Ol and M12 Ol), the data plot at slightly higher $\Delta^{33} \mathrm{~S}$ and lower $\Delta^{36} \mathrm{~S}$ compared to previously published data from MORB (Figure 2).

\section{Discussion}

An unusual observation of HIMU mantle sampled at Mangaia made by Cabral et al. (2013) is the negative $\delta^{34} \mathrm{~S}$ and the presence of S-MIF observed in individual sulfides by SIMS and by SF $_{6}$ techniques similar to those used here. The signatures observed by Cabral et al. (2013) yielded a field extending from $\delta^{34} \mathrm{~S}$ of $-3.3\left( \pm 2 \%\right.$ ) to $-17.3 \%$ o $\left( \pm 0.6 \%\right.$ ) and with near-zero to negative $\Delta^{33} \mathrm{~S}$. The observation of samples with negative $\Delta^{33} \mathrm{~S}$ that were measured both by SIMS and with one measurement by $\mathrm{SF}_{6}(-0.12 \pm 0.04 \%$, $2 \sigma)$ carried out at UMD (on sample MGA-B-47) is ascribed to the presence of subducted and recycled Archean components in the Mangaia source.

The data collected in this study on sulfide inclusions in mineral separates of $\mathrm{Ol}$ and Px from Mangaia also show a range of $\delta^{34} \mathrm{~S}$ but do not extend to values as negative as those presented in Cabral et al. (2013) $(-5.2 \%$ o to $+0.2 \%$ o $)$. Our data also lack the negative $\Delta^{33} \mathrm{~S}$ values seen in Cabral et al. (2013) and extend from to +0.006 to $+0.049 \%$ o $( \pm 0.016 \%$ o). Our data include analyses of sulfur from phenocrysts of one sample studied by Cabral et al. (2013) (MGA-B-25) for which they report a negative $\Delta^{33} \mathrm{~S}$ by SIMS, because this sample had not been analyzed using the $\mathrm{SF}_{6}$ method by Cabral et al. (2013). Cabral et al. (2013) reported a ${ }^{33} \mathrm{~S}$ depletion $(-0.12 \pm 0.04 \%, 2 \sigma)$ in an olivine separate from MGA-B-47. This was based on a measurement in our laboratory using the same fluorination and mass spectrometry as that is described in the methods section of this manuscript but with a wet chemistry protocol involving hydrochloric acid and $\mathrm{Cr}$ (II) to digest sulfide minerals. MGA-B-47 was not reanalyzed here due to lack of available olivine material with inclusions. The protocol we use here includes $\mathrm{HF}$, in addition to $\mathrm{HCl}$ and $\mathrm{Cr}$ (II), after Labidi et al. (2012). The HF technique is more efficacious at digesting silicate and thus can extract sulfides trapped within phenocrysts which may be missed by the $\mathrm{HCl}+\mathrm{Cr}$ (II) protocol used in Cabral et al. (2013). While the sulfide concentrations we 

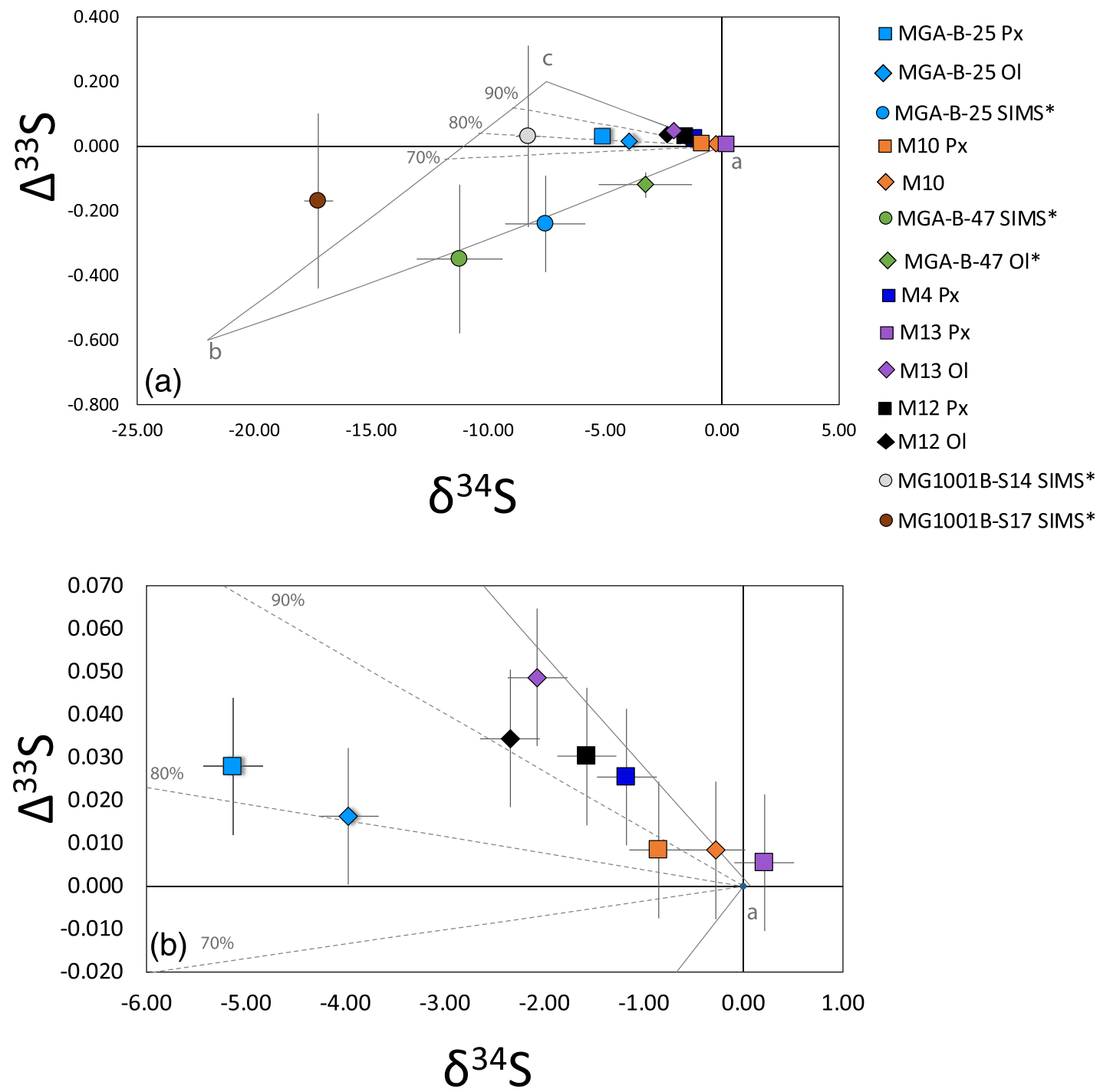

Figure 1. $\delta^{34} \mathrm{~S}$ versus $\Delta^{33} \mathrm{~S}$ for bulk sulfide data from sulfide inclusions in olivine and pyroxene phenocrysts. We also plot a mixing triangle between (a) the convective mantle $\left(\delta^{34} \mathrm{~S}=0, \Delta^{33} \mathrm{~S}=0\right)$, (b) the proposed recycled endmember from Cabral et al. (2013) $\left(\delta^{34} \mathrm{~S}=-22, \Delta^{33} \mathrm{~S}=-0.6\right)$, and $(\mathrm{c})$ our new proposed second recycled endmember $\left(\delta^{34} \mathrm{~S}=-7.5, \Delta^{33} \mathrm{~S}=+0.2\right)$. The dashed mixing lines within the triangle show that the S-isotope composition of bulk sulfide measurements represent a mixture of $\sim 80 \%$ the recycled (c) component, providing a potential explanation for the mismatch between the SIMS analysis and the bulk measurement.

observe (96 to $333 \mathrm{ppm}$ ) are higher than those reported in Cabral et al. (2013) for the $\mathrm{SF}_{6}$ analysis of olivine from MGA-B-47 ( 30 ppm), we cannot say whether this is due to some sulfide loss during sample processing in the laboratory or whether this reflects a lower sulfide content for the material from MGA-B-47 compared to the samples studied here. Regardless, both data sets (from Cabral et al., 2013, and this study) reveal significant variability for both $\delta^{34} \mathrm{~S}$ and $\Delta^{33} \mathrm{~S}$ that reflect some aspect of the history of these materials. We discuss below the arguments that support an origin associated with mixing of sulfur from different sources at the time of phenocryst formation.

\subsection{Phenocrysts and Links to Sulfide Concentration}

A unique aspect of this work is that our samples are not whole rock samples or glasses but rather phenocryst separates containing sulfide inclusions (Cabral et al., 2013). Sulfur is incompatible and thus not incorporated in olivine and pyroxenes structures (Gaetani \& Grove, 1997; Peach et al., 1990). Digestion of sulfide from inclusions such as those documented by Cabral et al. $(2013,2014)$ is also the most straightforward way to explain the amount of sulfur we see from digestion of phenocrysts. We observe between 100 and 


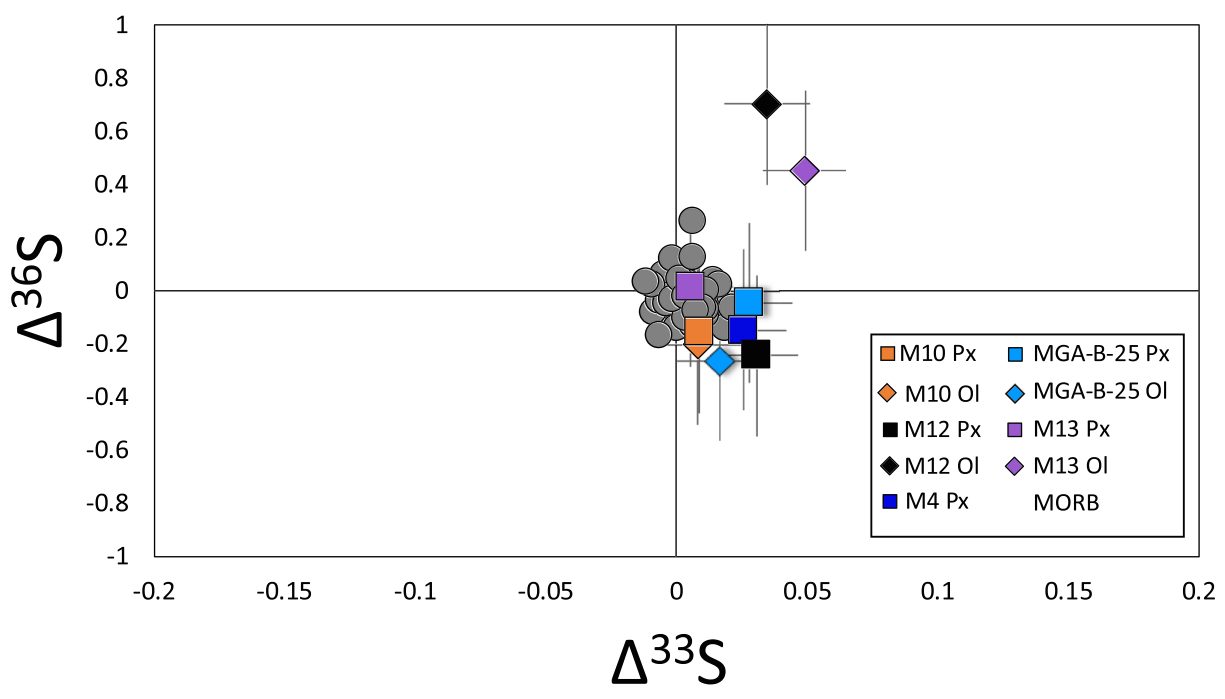

Figure 2. $\Delta^{33} \mathrm{~S}$ versus $\Delta^{36} \mathrm{~S}$ for bulk sulfide data from sulfide inclusions in olivine and pyroxene phenocrysts. With the exception of two data points from sulfide in olivine (M12 Ol and M13 Ol), the data overlap with data from MORB (Labidi et al., 2013; Labidi et al., 2014; Labidi \& Cartigny, 2016).

$300 \mathrm{ppm} \mathrm{S}$ in the bulk mineral separates (Table 1). Considering a silicate melt inclusion from Mangaia typically hosts $~ 1,000-2,000$ ppm S (Cabral et al., 2014), olivines would be required to be composed of 5-20 wt\% melt inclusions to account for our concentration data. This is significantly more than the $<0.1$ vol\% observed for phenocrysts (Cabral et al., 2014). Our S concentrations, however, are consistent with the presence of exsolved sulfide inclusions, which consist of approximately $32 \mathrm{wt} \% \mathrm{~S}$ and thus require $<0.02 \mathrm{vol} \%$ as sulfide inclusions in phenocrysts.

Trapping of sulfide liquids by growing phenocrysts is supported by observations in previous work: Nearperfect spherical-shaped sulfide inclusions were observed in olivine (often coexisting with silicate melt inclusions) by Cabral et al. $(2013,2014)$. The sulfide droplets were shown to display an association of $\mathrm{Cu}, \mathrm{Ni}$, and Fe sulfides that exsolved upon further cooling (Cabral et al., 2013), which is typical of magmatic sulfides observed in MORBs (Peach et al., 1990). For sulfide to be trapped as inclusions in phenocrysts, the associated melt must be sulfide saturated and contains coexisting sulfide liquid droplets. Such liquids could have exsolved from the silicate melt as a result of changes in melt composition associated with phenocryst formation or other processes. Liquid sulfide droplets would subsequently be trapped by growing olivine and pyroxene phenocrysts. Note that the amount of sulfide inclusions in any of the phenocrysts must reflect a variety of factors, including the level of sulfide saturation and the behavior of sulfide liquids and phenocrysts during the time leading up to and including entrapment. Similar to melt inclusions not yielding straightforward information for characterizing the liquid/mineral ratios of parental melts, the amount of sulfide inclusions may not directly constrain the sulfide concentration of the parent melt(s).

Melt inclusions in olivine phenocrysts from Mangaia record pressures of entrapment between 250 bar to $1.75 \mathrm{kbar}$ that translate into approximately 0.9 to $6.4 \mathrm{~km}$ depth (Cabral et al., 2014) and magmatic melt temperatures of $>1200^{\circ} \mathrm{C}$. Again, at these conditions sulfides are above the liquidus (Craig \& Kullerud, 1968). At these pressures, available thermodynamic models argue against sulfur degassing as a significant, or even likely, process (Burgisser et al., 2015; Gaillard et al., 2011). Once trapped, the phenocrysts encapsulate and isolate sulfide sulfur from further processing such as degassing upon eruption and posteruption weathering and provide snapshots of the diversity of magma chamber compositions prior to mixing and eruption. This process is analogous to the entrapment of melt inclusions which reveal heterogeneities inherited from mantle sources, before late mixing and eruption (e.g., Sobolev \& Shimizu, 1993). 


\subsection{Covariation of $\delta^{34} \mathrm{~S}$ and $\Delta^{33} \mathrm{~S}$ in Mangaia Samples M4, M10, M12, and M13}

We observe covariation of $\delta^{34} \mathrm{~S}$ and $\Delta^{33} \mathrm{~S}$ for sulfide from bulk Ol and Px in samples M4, M10, M12, and M13. It is conceivable that the covariation is the result of a high temperature process that yields mass-dependent fractionation. One may suggest that the Mangaia melts started with near-zero $\delta^{34} \mathrm{~S}$ and $\Delta^{33} \mathrm{~S}$ values, similar to MORB values (Labidi et al., 2014)and subsequently evolved toward low $\delta^{34} \mathrm{~S}$ and high $\Delta^{33} \mathrm{~S}$. However, the change of $\Delta^{33} \mathrm{~S}$ with $\delta^{34} \mathrm{~S}$ is not explained by the typical 0.515 exponent for high-temperature isotopic fractionations (Cao \& Liu, 2011; Hulston \& Thode, 1965). An exponent of $0.499 \pm 0.005$ is needed to fit the $\delta^{33} \mathrm{~S}-\delta^{34} \mathrm{~S}$ data (Figure S2) from this study (specifically that of M4, M10, M12, and M13). Although observations of exponents outside of 0.515 have been proposed for lower temperature processes (e.g., Deines, 2003; Eldridge \& Farquhar, 2018), we know of none that translate to the conditions at high temperature.

While the armoring of sulfides by phenocrysts likely makes them immune to effects of degassing, we examine degassing further since it is a common process in basalts and, as such, is a typical explanation for shifts to negative (or positive) $\delta^{34} \mathrm{~S}$ (Beaudry et al., 2018; de Moor et al., 2013; Mandeville et al., 2009). Given the mass fractionation scenario proposed by Fiege et al. (2015) at QFM (quartz-fayalite-magnetite) redox conditions, a loss of $85 \%$ of the sulfur as S (IV) during equilibrium (i.e., closed system) degassing would be required to achieve a $\delta^{34} \mathrm{~S}$ shift of $\sim-3 \%$. This is insufficient to account for the range of observed $\delta^{34} \mathrm{~S}$ in our data set and also that observed by Cabral et al. (2013). There is also no clear evidence that degassing can explain the change of $\Delta^{33} \mathrm{~S}$ with $\delta^{34} \mathrm{~S}$ from 0.515 by significant amounts. Although analyses of degassed OIB show shifts for $\delta^{34} \mathrm{~S}$, they show no significant $\Delta^{33} \mathrm{~S}$ variations, even when large $\delta^{34} \mathrm{~S}$ fractionations are produced (Beaudry et al., 2018; Dottin et al., 2020).

Partitioning of sulfur to $\mathrm{S}$ (VI) (sulfate) is also known to shift the $\delta^{34} \mathrm{~S}$ of residual sulfide to negative values. A case has been made for the presence of sulfate in OIBs (Jugo et al., 2010; Labidi et al., 2015). The equilibrium fractionation between sulfide and sulfate for $\delta^{34} \mathrm{~S}$ is $\sim 3 \%$ at $1200^{\circ} \mathrm{C}$ (Mandeville et al., 2009, and references within). The possibility that this accounts for a ${ }^{34} \mathrm{~S}$ depletion of the magnitude we observe would require a significant partitioning of sulfur to sulfate, and a sulfate/ $\Sigma$ sulfur ratio greater than values seen in OIB (e.g., 0.2 observed in Samoan lavas in Labidi et al., 2015). In the extreme case where $50 \%$ of total sulfur in the melt is sulfate, sulfides would be shifted from the bulk sulfur composition by $\sim 1.5 \%$. This fractionation is not large enough to account for the ${ }^{34} \mathrm{~S}$ depletion observed in the Mangaia sulfide inclusions. Furthermore, there is no evidence that, at high temperature, sulfide and sulfate would coexist with distinct $\Delta^{33} \mathrm{~S}$ values resulting from fractionation with a mass-dependent exponent different from 0.515.

Altogether, we conclude that there is no reasonable process identified to explain the $\delta^{34} \mathrm{~S}$ and $\Delta^{33} \mathrm{~S}$ covariation among sample M4, M10, M12, and M13. We argue that, instead, the covariation is rather likely caused by mixing processes in the mantle sources prior to eruption. Most of our data are accounted for by two-component mixing, between the ambient mantle and a component with low $\delta^{34} \mathrm{~S}$ and positive $\Delta^{33} \mathrm{~S}$ (Figure 1a, endmembers A and C). Olivine and pyroxene separates from a given sample are in S-isotope disequilibrium: They do not record identical $\delta^{34} \mathrm{~S}-\Delta^{33} \mathrm{~S}$ compositions. Instead, the data from the various mineral separates plot along the two-component mixing array $\delta^{34} \mathrm{~S}-\Delta^{33} \mathrm{~S}$ space (Figure 1). This indicates a contribution of two isotopically distinct magma sources that are heterogeneously delivered to the magma mixture and sampled by various phenocrysts in a given sample. Note that MGA-B-25 (measured via IRMS) does not fall along the two-component mixing relationship between endmembers A and $\mathrm{C}$. We suggest that this reflects the contribution of a third component: the recycled endmember identified in Cabral et al. (2013). We show in Figure 1a that this sample can be accounted for by a mixture between the ambient mantle, the endmember identified in Cabral et al. (2013) (Figure 1, endmember B), and the endmember identified in this study (Figure 1, endmember C).

The heterogeneous contributions of these three components recorded in phenocrysts of our samples are in agreement with previous arguments for magma mixing prior to eruption at Mangaia. This is supported by (1) highly variable forsterite content of olivine from individual Mangaia lavas and (2) Pb isotopic variability in individual olivine-hosted melt inclusions in Mangaia lavas (Saal et al., 1998) (but see Paul et al., 2011, and Cabral et al., 2014, who identify somewhat less Pb isotopic variability in Mangaia melt inclusions; Figure 3). Our suggestion is also in agreement with petrographic observations of resorption features on Ol and Px phenocrysts from M4, M10, M12, and M13 (Woodhead, 1996), which are consistent with magma mixing. 


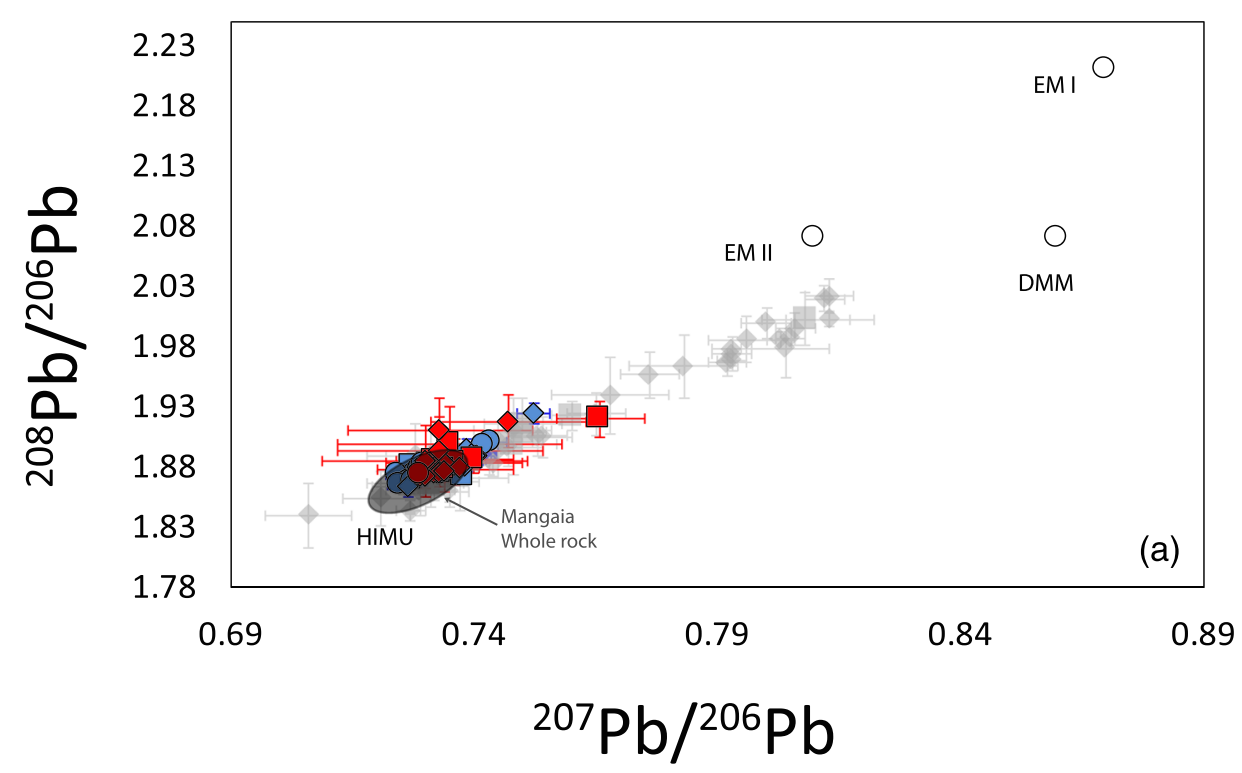

\begin{tabular}{|ll|}
\hline MBA-B-47 Saal et al. (1998) & MGA-B-25 Saal et al. (1998) \\
$\square$ MGA-B-25 Cabral et al. (2014) & $\triangle$ MG1002 Cabral et al. 2014 \\
o MG1001 Cabral et al. (2014) & $\diamond$ MGA-B-47 Cabral et al. (2014 \\
$\square$ MAN11 Paul et al. (2011) & $\diamond$ MAN4 Paul et al. (2011) \\
- MAN12 Paul et al. (2011) &
\end{tabular}

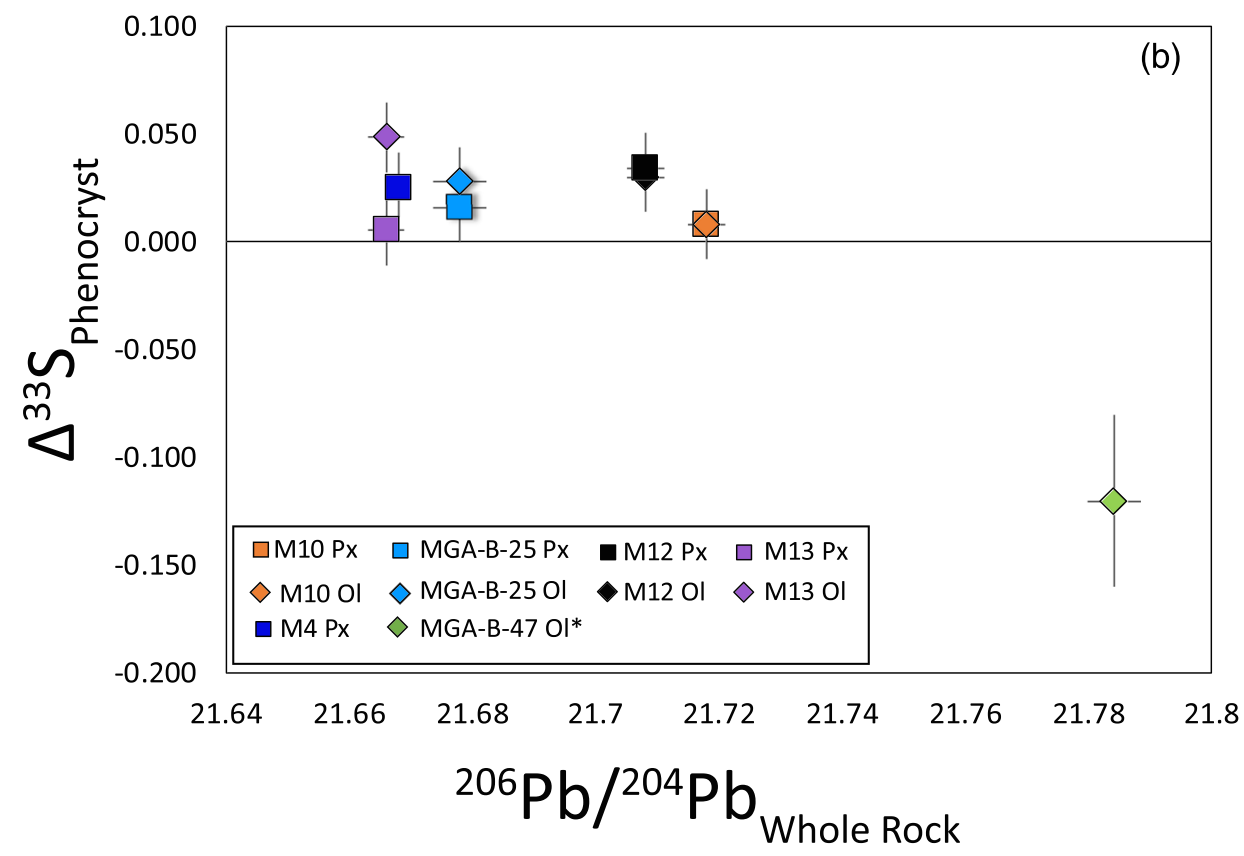

Figure 3. Whole rock $\mathrm{Pb}$ isotopes of Mangaia lavas, $\mathrm{Pb}$ isotopes in olivine-hosted melt inclusions from Mangaia, and $\Delta^{33} \mathrm{~S}$ of sulfide in melt inclusions within olivine and pyroxene phenocrysts. (a) ${ }^{208} \mathrm{~Pb} /{ }^{206} \mathrm{~Pb}$ versus ${ }^{207} \mathrm{~Pb} /{ }^{206} \mathrm{~Pb}$ for olivine-hosted melt inclusions from Mangaia. Melt inclusion data are published in Cabral et al. (2014), Paul et al. (2011) and Saal et al. (1998), and whole rock data are shown for reference Hauri and Hart (1993) and Woodhead (1996). Data from melt inclusions demonstrate $\mathrm{Pb}$ isotope heterogeneity in a single sample that suggests mixing of multiple melt sources. (b) $\Delta^{33} \mathrm{~S}$ versus ${ }^{206} \mathrm{~Pb} /{ }^{204} \mathrm{~Pb}$. Pb isotope data are from whole rock measurements and S-isotope data represent bulk sulfide digestions of sulfur in melt inclusions within olivine and pyroxene phenocrysts. *The $\mathrm{S}$ measurement of bulk sulfide in olivine from MGA-B-47 was presented in Cabral et al. (2013). The S-isotope data and $\mathrm{Pb}$ isotope data show potential for a relationship that suggest mixing of multiple S sources and would link MGA-B-47 to an older mantle component. 


\subsection{Nature and Age of the Recycled Components}

The HIMU mantle reservoir is generally thought to reflect mantle mixed with subducted oceanic crust that experienced sulfide loss, causing depletion in $\mathrm{Pb}$ (Chauvel et al., 1992; Kelley et al., 2005; Lassiter et al., 2003); however, some proposals also call for a mantellic origin (Thirlwall, 1997), formation by recycled carbonate (Castillo, 2015; Castillo, 2016; Castillo et al., 2018), recycled serpentinites (Kendrick et al., 2017), carbonatitic metasomatism of the subcontinental lithospheric mantle that in turn delaminated and sank to the core-mantle boundary (Weiss et al., 2016), or an origin in metasomatic veins hosted in ancient subducted mantle lithosphere (Pilet et al., 2008). A wide range of ages have been proposed for the U/Pb fractionation that generated HIMU ( 550 Ma to 3.0 Ga; Hauri and Hart, 1993; Mazza et al., 2019; Nebel et al., 2013; Thirlwall, 1997). Below, we offer a hypothetical scenario that allows the S-isotope data to be reconciled in light of the most common model for HIMU source generation: altered oceanic crust $(\mathrm{AOC})+$ peridotite $+\mathrm{a}$ carbonated contribution (e.g., Jackson \& Dasgupta, 2008)

\subsubsection{Subduction Processes}

When including an AOC component, we must consider the potential effect of sulfide loss during slab subduction on $\delta^{34} \mathrm{~S}$. If a parcel of subducted oceanic crust started with $\sim 1,000$ ppm S (Alt \& Shanks, 2011; Rouxel, Ono et al., 2008) with an average $\delta^{34} \mathrm{~S}$ of $+3 \%$ (Alt, 1995), and assuming $\mathrm{Pb}$ is hosted in sulfides (Kelley et al., 2003), Pb loss by sulfide breakdown in the subduction zone results in 400-20 ppm S (i.e., $60 \%$ to $98 \%$ sulfide loss) in the HIMU mantle source. A process resulting in the preferential loss of ${ }^{34} \mathrm{~S}$ could explain the unusually low $\delta^{34} \mathrm{~S}$ observed at Mangaia. Assuming 60\% sulfide loss occurred during slab devolatilization, such would require an average fractionation of $\sim 14 \%$ o between the fluid (preferentially partitioning ${ }^{34} \mathrm{~S}$ ) and the residual slab (preferentially retaining ${ }^{32} \mathrm{~S}$ ) to explain our data, and a $\sim 34 \%$ fluid-slab residue fractionation to explain the lowest $\delta^{34} \mathrm{~S}$ in Cabral et al. (2013). This calculation represents an upper limit. Instrumental bias during analytical sessions results in a fractionation on $\delta^{34} \mathrm{~S}$ as large as $-3.8 \pm 0.7$ (1SD) (Cabral et al., 2013) when calibrating pyrrhotite measurements. If $98 \%$ of sulfide was lost, an average fractionation of $\sim 9 \%$ o between the fluid and the residual slab to explain our data, and a $\sim 21 \%$ o fluid-slab residue fractionation to explain the lowest $\delta^{34} \mathrm{~S}$ in Cabral et al. (2013). These fractionations are large for temperatures associated with slab dehydration and are not observed in studies of metamorphism (Li et al., 2020). We note additionally that in diamond sulfides, subducted components typically do not show evidence for $\mathrm{S}$ isotopic fractionation associated with subduction of MIF-Sulfur, displaying $\delta^{34} \mathrm{~S} \geq 0$ and $\Delta^{33} \mathrm{~S} \geq 0$ (Farquhar et al., 2002; Smit et al., 2019; Thomassot et al., 2009) and at localities where $\delta^{34}$ S is fractionated (Beaudry et al., 2018; Hofmann et al., 2009; Labidi et al., 2013, 2015; Roerdink et al., 2016; Thomassot et al., 2015), the composition is attributed to that of the protolith and not subduction processes. In our study we adopt this interpretation and conclude that while sulfide breakdown in subduction zones causes $\mathrm{U} / \mathrm{Pb}$ fractionation in HIMU, it may not account for variable $\delta^{34}$ S observed globally, between Mangaia (this study; Cabral et al., 2013) and other HIMU locations (e.g., Beaudry et al., 2018).

\subsubsection{Mixing AOC, Peridotitic Mantle, and a Carbonated Component}

The variable $\delta^{34} \mathrm{~S}$ values of HIMU may be inherited from the composition of the protoliths, prior to subduction. Modern AOC has, on average, a $\delta^{34} \mathrm{~S}$ that is positive due to the widespread occurrence of massive hydrothermal sulfides that generally carry positive values (Alt, 1995). While such material is consistent with the positive $\delta^{34}$ S estimated for HIMU at other localities (e.g., Labidi et al., 2014; Labidi \& Cartigny, 2016), it contrasts with the low $\delta^{34} \mathrm{~S}$ values in HIMU Mangaia samples observed here. The bulk $\delta^{34} \mathrm{~S}$ composition of the first kilometer of oceanic crust is estimated at -6 to $-7 \%$ (Alt \& Shanks, 2011; Rouxel, Shanks, et al., 2008), with positive $\Delta^{33} \mathrm{~S}$ up to $+0.162 \%$ \pm 0.014 (Ono et al., 2012). This first kilometer is where the deep biosphere is able to process seawater sulfate and precipitate biogenic sulfides. If this portion of the slab is the contributor of the AOC component in HIMU, such can explain the low $\delta^{34}$ S values at Mangaia with the caveat that a unique process is required to contribute a specific parcel of a slab (specially the upper portion) to the Mangaia mantle source.

An additional component we must consider in that of the carbonated component in HIMU lavas (Jackson \& Dasgupta, 2008, and references therein). Cabral et al. (2014) argue for a carbonated source at HIMU Mangaia on the basis of inferred (predegassing) high primary $\mathrm{CO}_{2}$ in melt inclusions that are required to explain their elevated $\mathrm{CaO} / \mathrm{Al}_{2} \mathrm{O}_{3}$ and low $\mathrm{SiO}_{2}$, as well as the presence of carbonatite observed in Mangaia melt inclusions by Saal et al. (1998) and Yurimoto et al. (2004). Castillo et al. (2018) suggest a component of 
recycled carbonate in the source of HIMU, and such may be the source of carbonation for the HIMU mantle source. If the carbonated component originates from marine carbonates, or carbonated shales, as suggested by Castillo et al. (2018), they could have influenced the isotopic composition of sulfides. Archean and Proterozoic carbonates are not typically sulfide rich (Veizer et al., 1989; Veizer Clayton, \& Hinton, 1992; Veizer, Plumb, et al., 1992) and frequently possess positive $\delta^{34} \mathrm{~S}$; thus these lithologies do not provide an obvious way to connect the carbonated component to the full negative $\delta^{34} \mathrm{~S}$ at Mangaia; however, the possibility of such a connection remains.

We can establish a simple mass balance of the carbonated component and AOC component in the HIMU mantle source. In our scenario, the carbonated component has a $\delta^{34} \mathrm{~S}$ of $\approx-7.5 \%$ (Figure 1) and $<10,000$ ppm S estimated from carbonatite sulfur contents as a proxy for the carbonated component (Gold, 1963), the AOC component also has a $\delta^{34} \mathrm{~S}$ of $\approx-7.5 \%$ (Figure 1) but <400 ppm S (Labidi et al., 2014), and the peridotitic mantle has a $\delta^{34} \mathrm{~S}$ of $=0 \%$ and $200 \mathrm{ppm} \mathrm{S}$ (Lorand \& Luguet, 2016). It is clear that regardless of the AOC-peridotite mixing ratio, the S-isotope budget would be dominated by relatively small contributions of the carbonated component, irrespective of the $\delta^{34} \mathrm{~S}$ compositions of AOC and peridotite. The AOC contribution was suggested to be as high as 50\% in the source of Mangaia (Hauri \& Hart, 1993). We suggest that in addition to $50 \%$ recycled AOC in the HIMU mantle source, $<10 \%$ of the carbonated material is necessary to satisfy our mixing model (Figure 1), in line with numerous suggestions for a C-rich component in the Mangaia mantle source (e.g., Cabral et al., 2014; Jackson \& Dasgupta, 2008; Saal et al., 1998; Yurimoto et al., 2004).

\subsubsection{Unusual $\delta^{34} \mathrm{~S}$ in HIMU OIB}

The contribution of negative $\delta^{34} \mathrm{~S}$ components at Mangaia is unusual. It contrasts with recycled components observed at Samoa (EM II) and Discovery (EM I) hotspots, where positive $\delta^{34} \mathrm{~S}$ values are observed (Dottin et al., 2020; Labidi et al., 2013, 2015). Another HIMU hotspot, the Canary Islands, also shows a mantle source with positive $\delta^{34} \mathrm{~S}$ values (Beaudry et al., 2018), and MORBs that incorporate variable amounts of HIMU components (Sobolev et al., 2007) appear to be influenced by a source with $\delta^{34} \mathrm{~S}=+3 \pm 2 \%$ o (Labidi et al., 2014; Labidi \& Cartigny, 2016). Importantly, the unusual ${ }^{34}$ S-depleted signature present in the Mangaia samples (this study and Cabral et al., 2013) as well as the EM1 Pitcairn lavas in Delavault et al. (2016) are associated with variable $\Delta^{33} \mathrm{~S}$ that may be linked to the ages of the contributing source components.

It has been suggested that recycling of negative $\delta^{34} \mathrm{~S}$ components may have occurred in the Archean (Cabral et al., 2013; Delavault et al., 2016; Farquhar \& Jackson, 2016) and the Proterozoic (Canfield, 2004) as a way to offset the positive $\delta^{34} \mathrm{~S}$ components observed in sediments. Negative $\delta^{34} \mathrm{~S}$ values are not typically observed in Archean rocks, although they have been observed among positive $\delta^{34} \mathrm{~S}$ values in some formations, such as barite deposits (Roerdink et al., 2016), gabbros (Thomassot et al., 2015), Archean conglomerates (Hofmann et al., 2009), and metamosphosed Archean crust (Kitayama et al., 2012). This hypothesis posits that an underrepresented reservoir of ${ }^{34} \mathrm{~S}$-depleted material was lost to recycling and stored in the deep mantle, in the source of hotspots like Mangaia. EM-2 and EM-1 locations, where sedimentary recycling is suspected to occur, show the contribution of a crustal component with positive $\delta^{34} \mathrm{~S}$ and near-zero $\Delta^{33} \mathrm{~S}$ (Labidi et al., 2013, 2015) and negative $\delta^{34} \mathrm{~S}$ associated with variable $\Delta^{33} \mathrm{~S}$ (Delavault et al., 2016), respectively. Thus evidence from mantle samples suggests recycling of sulfur with both negative and positive $\delta^{34} \mathrm{~S}$. Our measurements, along with those of Cabral et al. (2014), indicated that at Mangaia the negative $\delta^{34} \mathrm{~S}$ dominates.

\subsubsection{Information on Relative Age From $\Delta^{36} \mathrm{~S}$ Data}

Additional constraints on the relative age of sulfur contributing slightly positive $\Delta^{33} \mathrm{~S}$ may be provided by the relationship between $\Delta^{33} \mathrm{~S}$ and $\Delta^{36} \mathrm{~S}$. Archean rocks typically show covariation of $\Delta^{33} \mathrm{~S}$ and $\Delta^{36} \mathrm{~S}$ with a slope of -1 (Farquhar et al., 2007). This means that if a $\Delta^{33} \mathrm{~S} 0.05 \%$, like that observed here, results from the contribution of an Archean protolith in the Mangaia mantle source, the corresponding $\Delta^{36} \mathrm{~S}$ is predicted to be $-0.05 \%$, which is not resolved with our uncertainty on $\Delta^{36} \mathrm{~S}( \pm 0.3 \%$ ). Post-Archean rocks show covariation of $\Delta^{33} \mathrm{~S}$ and $\Delta^{36} \mathrm{~S}$ with a slope of $\sim-7$, which would result in a very small $\Delta^{36} \mathrm{~S}$ shift to $-0.4 \%$, which would be marginally resolvable given our estimated uncertainty. Our data generally plot below (more negative $\Delta^{36} \mathrm{~S}$ ) and to the right (more positive $\Delta^{33} \mathrm{~S}$ ) of typical MORB (Figure 2). The shift for $\Delta^{36} \mathrm{~S}$ of the data cluster is more consistent with a biological fractionation than a mass-independent (Archean) fractionation, but an 
Archean component with little to no mass-independent anomaly could satisfy our observations. However, we argue the most parsimonious explanation for the data here is that the material we measured is postArchean, in addition to the contribution of Archean S (as identified in Cabral et al., 2013) in the MGA-B25 data presented here. We note that the data do, however, have large uncertainties, and our hypothesis would need to be confirmed with further analyses.

\subsection{Recycling Two Reservoir Ages}

With the samples presented here, the $\mathrm{Pb}$ isotope data of whole rock basalts from Woodhead (1996) and Hauri and Hart (1993) all show extreme ${ }^{206} \mathrm{~Pb} /{ }^{204} \mathrm{~Pb}$, indicating the endmember HIMU character of the Mangaia mantle source, consistent with modern geochemical studies of Mangaia lavas (Hanyu et al., 2011, and references therein). Further constraints on the nature of the recycled components at Mangaia may be provided in relationships between ${ }^{206} \mathrm{~Pb} /{ }^{204} \mathrm{~Pb}$ and sulfur isotopes: Whole rock $\mathrm{Pb}$ isotope and bulk sulfide S-isotope measurements reveal heterogeneity in Mangaia lavas. There is some Pb isotopic heterogeneity in the whole rocks, but the $\mathrm{Pb}$ isotope compositions of individual melt inclusions in Mangaia lavas reveal substantially more heterogeneity than the whole rock data (Saal et al., 1998; Yurimoto et al., 2004) though recent reports of $\mathrm{Pb}$-isotopic heterogeneity in Mangaia inclusions reveal somewhat less heterogeneity (Cabral et al., 2014; Paul et al., 2011) (Figure 3a). Thus, compared to the bulk olivine and clinopyroxene analyses presented here, the greater $\mathrm{S}$ isotopic heterogeneity in individual melt inclusions (Cabral et al., 2013) may not be surprising in this light. Additionally, the remarkable $\delta^{34}$ S disequilibrium between olivine and pyroxene in a single sample (this study) supports a scenario in which the melt inclusions are sampling isotopically heterogenous compositions, as supported by the $\mathrm{Pb}$-isotopic heterogeneity in Mangaia melt inclusions.

Our S-isotope data are from mineral separates extracted from the same whole rocks presented in Woodhead (1996) and Hauri and Hart (1993). Interestingly, the S-isotope compositions presented in this study and Cabral et al. (2013) from mineral separates show the potential for a relationship between whole rock $\mathrm{Pb}$ isotopes and bulk $\mathrm{S}$ isotopes from mineral separates (Figure 3b), where whole rock ${ }^{206} \mathrm{~Pb} /{ }^{204} \mathrm{~Pb}$ increases with decreasing $\Delta^{33} \mathrm{~S}$ in mineral separates. We note however that the whole rock $\mathrm{Pb}$ isotope data use an older TIMS method that did not employ double or triple spike to track in-run mass fractionation (Hauri \& Hart, 1993; Woodhead, 1996). Thus, these older TIMS data are likely to have larger uncertainties than were originally reported by these authors (Hauri \& Hart, 1993; Woodhead, 1996). Nonetheless, the variability in $\mathrm{Pb}$ isotope compositions of melt inclusions may be indicative of mixing of multiple compositions in the HIMU mantle source beneath Mangaia, suggesting the relationship we observe between bulk $\mathrm{S}$-isotope compositions from mineral separates and whole rock $\mathrm{Pb}$ isotope compositions, also reflects variability in the HIMU mantle source. If real, the data would reflect mixing between components of different ages, where higher ${ }^{206} \mathrm{~Pb} /{ }^{204} \mathrm{~Pb}$ and the negative $\Delta^{33} \mathrm{~S}$ in Mangaia is associated with an older mantle component.

\section{Conclusions}

The data presented here on sulfide inclusions within olivine and pyroxene phenocrysts from Mangaia reveal a heterogeneous S-isotope composition. Compositions range from $-5.13 \%$ o to $+0.21 \%$ o $( \pm 0.3),+0.006 \%$ o to $+0.049 \%$ ( $( \pm 0.016),-0.81 \%$ o to $+0.69 \%$ o $( \pm 0.3)$ for $\delta^{34} \mathrm{~S}, \Delta^{33} \mathrm{~S}$, and $\Delta^{36} \mathrm{~S}$, respectively. The $\Delta^{33} \mathrm{~S}$ values are different from those presented in Cabral et al. (2013) who generally show negative $\Delta^{33} \mathrm{~S}$ and indicate that some, possibly the preponderance, of HIMU sulfur sampled at Mangaia comes from a different reservoir, likely of younger post-Archean age. Both studies, however, report ${ }^{34} \mathrm{~S}$-depleted sulfur, and this appears to be a characteristic of Mangaia HIMU that we attribute to a crustal origin, following observations by studies like Rouxel, Shanks, et al. (2008) and Alt and Shanks (2011). Thus, there appears to be variability in the material derived from the same plume plumbing system at Mangaia.

This work focuses on S-isotope compositions of bulk sulfide in melt inclusions in $\mathrm{Ol}$ and Px from the same sample, and this sulfur is not in isotopic equilibrium but shows covariation in $\delta^{34} \mathrm{~S}$ and $\Delta^{33} \mathrm{~S}$ which we link to the capturing of S-isotope compositions of various melts as they are added to the magma chamber. The data for Mangaia presented here, and provided by Cabral et al. (2013), support mixing of melts with at least three distinct sulfur isotope endmembers: (1) a convective mantle component with $\delta^{34} \mathrm{~S}=0$ and $\Delta^{33} \mathrm{~S}=0$; (2) 
a component with negative $\delta^{34} \mathrm{~S}$ and slightly positive $\Delta^{33} \mathrm{~S}$, and (3) a component with negative $\delta^{34} \mathrm{~S}$ and negative $\Delta^{33}$ S.

\section{Data Availability Statement}

Data set for this manuscript exists as open access in the Digital Repository at the University of Maryland (DRUM; https://doi.org/10.13016/zs1g-knnj).

\section{Acknowledgments}

We acknowledge funding for this project from National Science Foundation EAR-1348082 (to J. F. and M. J.). We also thank Editor Marie Edmonds for handling our manuscript and for helpful reviews from Emilie Thomassot and an anonymous reviewer.

\section{References}

Alt, J. C. (1995). Sulfur isotopic profile through the oceanic crust: Sulfur mobility and seawater-crustal sulfur exchange during hydrothermal alteration. Geology, 23(7), 585-588. https://doi.org/10.1130/0091-7613(1995)023<0585:SIPTTO >2.3.CO;2

Alt, J. C., \& Shanks, W. C. (2011). Microbial sulfate reduction and the sulfur budget for a complete section of altered oceanic basalts, IODP Hole 1256D (eastern Pacific). Earth and Planetary Science Letters, 310(1-2), 73-83. https://doi.org/10.1016/j.epsl.2011.07.027

Antonelli, M. A., Kim, S.-T., Peters, M., Labidi, J., Cartigny, P., Walker, R. J., et al. (2014). Early inner solar system origin for anomalous sulfur isotopes in differentiated protoplanets. Proceedings of the National Academy of Sciences, 111, 17,749-17,754. http://www.ncbi.nlm. nih.gov/pubmed/25453079

Beaudry, P., Longpré, M.-A., Economos, R., Wing, B. A., Bui, T. H., \& Stix, J. (2018). Degassing-induced fractionation of multiple sulphur isotopes unveils post-Archaean recycled oceanic crust signal in hotspot lava. Nature Communications, 9(1), 5093. https://doi.org/ 10.1038/s41467-018-07527-w

Burgisser, A., Alletti, M., \& Scaillet, B. (2015). Simulating the behavior of volatiles belonging to the C-O-H-S system in silicate melts under magmatic conditions with the software D-compress. Computational Geosciences, 79, 1-14. https://doi.org/10.1016/j.cageo.2015.03.002

Cabral, R. A., Jackson, M. G., Koga, K. T., Rose-Koga, E. F., Hauri, E. H., Whitehouse, M. J., et al. (2014). Volatile cycling of $\mathrm{H}_{2} \mathrm{O}$, CO $\mathrm{CO}_{2}$, F, and $\mathrm{Cl}$ in the HIMU mantle: A new window provided by melt inclusions from oceanic hot spot lavas at Mangaia, Cook Islands. Geochemistry, Geophysics, Geosystems, 15, 4445-4467. https://doi.org/10.1002/2014GC005473

Cabral, R. A., Jackson, M. G., Rose-Koga, E. F., Koga, K. T., Whitehouse, M. J., Antonelli, M. A., et al. (2013). Anomalous sulphur isotopes in plume lavas reveal deep mantle storage of Archaean crust. Nature, 496(7446), 490-493. https://doi.org/10.1038/nature12020

Canfield, D. E. (2004). The evolution of the Earth surface sulfur reservoir. American Journal of Science, 304(10), 839-861. https://doi.org/ 10.2475/ajs.304.10.839

Cao, X., \& Liu, Y. (2011). Equilibrium mass-dependent fractionation relationships for triple oxygen isotopes. Geochimica et Cosmochimica Acta, 75(23), 7435-7445. https://doi.org/10.1016/j.gca.2011.09.048

Castillo, P. R. (2015). The recycling of marine carbonates and sources of HIMU and FOZO ocean island basalts. Lithos, 216, $254-263$. https://doi.org/10.1016/j.lithos.2014.12.005

Castillo, P. R. (2016). A proposed new approach and unified solution to old Pb paradoxes. Lithos, 252, 32-40. https://doi.org/10.1016/j. lithos.2016.02.015

Castillo, P. R., MacIsaac, C., Perry, S., \& Veizer, J. (2018). Marine carbonates in the mantle source of oceanic basalts: Pb isotopic constraints. Scientific Reports, 8, 1-7.

Chauvel, C., Hofmann, A. W., \& Vidal, P. (1992). HIMU-EM: The French Polynesian connection. Earth and Planetary Science Letters, 110(1-4), 99-119. https://doi.org/10.1016/0012-821X(92)90042-T

Craig, J. R., \& Kullerud, G. (1968). Phase relations and mineral assemblages in the copper-lead-sulfur system. American Mineralogist Journal of Earth and Planetary Materials., 53, 145-161.

Deines, P. (2003). A note on intra-elemental isotope effects and the interpretation of non-mass-dependent isotope variations. Chemical Geology, 199(1-2), 179-182. https://doi.org/10.1016/S0009-2541(03)00076-7

Delavault, H., Chauvel, C., Thomassot, E., Devey, C. W., \& Dazas, B. (2016). Sulfur and lead isotopic evidence of relic Archean sediments in the Pitcairn mantle plume. Proceedings of the National Academy of Sciences, 113(46), 12,952-12,956. https://doi.org/10.1073/ pnas. 1523805113

de Moor, J. M., Fischer, T. P., Sharp, Z. D., King, P. L., Wilke, M., Botcharnikov, R. E., et al. (2013). Sulfur degassing at Erta Ale (Ethiopia) and Masaya (Nicaragua) volcanoes: Implications for degassing processes and oxygen fugacities of basaltic systems. Geochemistry, Geophysics, Geosystems, 14, 4076-4108. https://doi.org/10.1002/ggge.20255

Dottin, J. W. III, Labidi, J., Lekic, V., Jackson, M. G., \& Farquhar, J. (2020). Sulfur isotope characterization of primordial and recycled sources feeding the Samoan mantle plume. Earth and Planetary Science Letters, 534, 116073. https://doi.org/10.1016/j. epsl.2020.116073

Eldridge, D. L., \& Farquhar, J. (2018). Rates and multiple sulfur isotope fractionations associated with the oxidation of sulfide by oxygen in aqueous solution. Geochimica et Cosmochimica Acta, 237, 240-260. https://doi.org/10.1016/j.gca.2018.06.030

Farquhar, J., \& Jackson, M. (2016). Missing Archean sulfur returned from the mantle. Proceedings of the National Academy of Sciences, 113(46), 12,893-12,895. https://doi.org/10.1073/pnas.1616346113

Farquhar, J., Wing, B. A., McKeegan, K. D., Harris, J. W., Cartigny, P., \& Thiemens, M. H. (2002). Mass-independent sulfur of inclusions in diamond and sulfur recycling on early Earth. Science (5602), 298, 2369-2372.

Fiege, A., Holtz, F., Behrens, H., Mandeville, C. W., Shimizu, N., Crede, L. S., \& Göttlicher, J. (2015). Experimental investigation of the S and S-isotope distribution between $\mathrm{H} 2 \mathrm{O}-\mathrm{S} \pm \mathrm{Cl}$ fluids and basaltic melts during decompression. Chemical Geology, 393, 36-54. https:// doi.org/10.1016/j.chemgeo.2014.11.012

Gaetani, G. A., \& Grove, T. L. (1997) Partitioning of moderately siderophile elements among olivine, silicate melt, and sulfide melt: Constraints on core formation in the Earth and Mars.

Gaillard, F., Scaillet, B., \& Arndt, N. T. (2011). Atmospheric oxygenation caused by a change in volcanic degassing pressure. Nature, 478(7368), 229-232. https://doi.org/10.1038/nature10460

Gold, D. P. (1963). Average chemical composition of carbonatites. Economic Geology, 58(6), 988-991. https://doi.org/10.2113/ gsecongeo.58.6.988

Hanyu, T., Tatsumi, Y., Senda, R., Miyazaki, T., Chang, Q., Hirahara, Y., et al. (2011). Geochemical characteristics and origin of the HIMU reservoir: A possible mantle plume source in the lower mantle. Geochemistry, Geophysics, Geosystems, 12, Q0AC09. https:/doi.org/ 10.1029/2010GC003252 
Hauri, E. H., \& Hart, S. R. (1993). ReOs isotope systematics of HIMU and EMII oceanic island basalts from the south Pacific Ocean. Earth and Planetary Science Letters, 114(2-3), 353-371. https://doi.org/10.1016/0012-821X(93)90036-9

Hofmann, A., Bekker, A., Rouxel, O., Rumble, D., \& Master, S. (2009). Multiple sulphur and iron isotope composition of detrital pyrite in Archaean sedimentary rocks: A new tool for provenance analysis. Earth and Planetary Science Letters, 286(3-4), 436-445. https://doi. org/10.1016/j.epsl.2009.07.008

Hulston, J. R., \& Thode, H. G. (1965). Variations in the S S and S contents of meteorites and their relation to chemical and nuclear effects. Journal of Geophysical Research, 70(14), 3475-3484. https://doi.org/10.1029/JZ070i014p03475

Jackson, M. G., \& Dasgupta, R. (2008). Compositions of HIMU, EM1, and EM2 from global trends between radiogenic isotopes and major elements in ocean island basalts. Earth and Planetary Science Letters, 276(1-2), 175-186. https://doi.org/10.1016/j. epsl.2008.09.023

Jugo, P. J., Wilke, M., \& Botcharnikov, R. E. (2010). Sulfur K-edge XANES analysis of natural and synthetic basaltic glasses: Implications for S speciation and S content as function of oxygen fugacity. Geochimica et Cosmochimica Acta, 74(20), 5926-5938. https://doi.org/10.1016/ j.gca.2010.07.022

Kelley, K. A., Plank, T., Farr, L., Ludden, J., \& Staudigel, H. (2005). Subduction cycling of U, Th, and Pb. Earth and Planetary Science Letters, 234(3-4), 369-383. https://doi.org/10.1016/j.epsl.2005.03.005

Kelley, K. A., Plank, T., Ludden, J., \& Staudigel, H. (2003). Composition of altered oceanic crust at ODP Sites 801 and 1149. Geochemistry, Geophysics, Geosystems, 4, 8910. https://doi.org/10.1029/2002GC000435

Kendrick, M. A., Hémond, C., Kamenetsky, V. S., Danyushevsky, L., Devey, C. W., Rodemann, T., et al. (2017). Seawater cycled throughout Earth's mantle in partially serpentinized lithosphere. Nature Geoscience, 10(3), 222-228. https://doi.org/10.1038/ngeo2902

Kitayama, Y., Thomassot, E., O'Neil, J., \& Wing, B. A. (2012). Sulfur-and oxygen-isotope constraints on the sedimentary history of apparent conglomerates from the Nuvvuagittuq Greenstone Belt (Nunavik, Québec). Earth and Planetary Science Letters, 355, $271-282$.

Labidi, J., \& Cartigny, P. (2016). Negligible sulfur isotope fractionation during partial melting: Evidence from Garrett transform fault basalts, implications for the late-veneer and the hadean matte. Earth and Planetary Science Letters, 451, 196-207. https://doi.org/ 10.1016/j.epsl.2016.07.012

Labidi, J., Cartigny, P., Birck, J. L., Assayag, N., \& Bourrand, J. J. (2012). Determination of multiple sulfur isotopes in glasses: A reappraisal of the MORB $\delta 34$ S. Chemical Geology, 334, 189-198. https://doi.org/10.1016/j.chemgeo.2012.10.028

Labidi, J., Cartigny, P., Hamelin, C., Moreira, M., \& Dosso, L. (2014). Sulfur isotope budget (32S, 33S, 34S and 36S) in Pacific-Antarctic ridge basalts: A record of mantle source heterogeneity and hydrothermal sulfide assimilation. Geochimica et Cosmochimica Acta, 133, 47-67. Available at:. https://doi.org/10.1016/j.gca.2014.02.023

Labidi, J., Cartigny, P., \& Jackson, M. G. (2015). Multiple sulfur isotope composition of oxidized Samoan melts and the implications of a sulfur isotope 'mantle array' in chemical geodynamics. Earth and Planetary Science Letters, 417, 28-39. https://doi.org/10.1016/j. epsl.2015.02.004

Labidi, J., Cartigny, P., \& Moreira, M. (2013). Non-chondritic sulphur isotope composition of the terrestrial mantle. Nature, 501(7466), 208-211. Available at:. https://doi.org/10.1038/nature12490

Lassiter, J. C., Blichert-Toft, J., Hauri, E. H., \& Barsczus, H. G. (2003). Isotope and trace element variations in lavas from Raivavae and Rapa, Cook-Austral islands: Constraints on the nature of HIMU- and EM-mantle and the origin of mid-plate volcanism in French Polynesia. Chemical Geology, 202(1-2), 115-138. https://doi.org/10.1016/j.chemgeo.2003.08.002

Li, Y., Yu, H., Gu, X., Guo, S., \& Huang, F. (2020). Silicon isotopic fractionation during metamorphic fluid activities: Constraints from eclogites and ultrahigh-pressure veins in the Dabie orogen, China. Chemical Geology, 540, 119550. https://doi.org/10.1016/j. chemgeo.2020.119550

Lorand, J.-P., \& Luguet, A. (2016). Chalcophile and siderophile elements in mantle rocks: Trace elements controlled by trace minerals. Reviews in Mineralogy and Geochemistry, 81(1), 441-488. https://doi.org/10.2138/rmg.2016.81.08

Mandeville, C. W., Webster, J. D., Tappen, C., Taylor, B. E., Timbal, A., Sasaki, A., et al. (2009). Stable isotope and petrologic evidence for open-system degassing during the climactic and pre-climactic eruptions of Mt. Mazama, Crater Lake, Oregon. Geochimica et Cosmochimica, 73, 2978-3012. https://doi.org/10.1016/j.gca.2009.01.019

Mazza, S. E., Gazel, E., Bizimis, M., Moucha, R., Béguelin, P., Johnson, E. A., et al. (2019). Sampling the volatile-rich transition zone beneath Bermuda. Nature, 569(7756), 398-403. https://doi.org/10.1038/s41586-019-1183-6

Nebel, O., Arculus, R. J., van Westrenen, W., Woodhead, J. D., Jenner, F. E., Nebel-Jacobsen, Y. J., et al. (2013). Coupled Hf-Nd-Pb isotope co-variations of HIMU oceanic island basalts from Mangaia, Cook-Austral islands, suggest an Archean source component in the mantle transition zone. Geochimica et Cosmochimica Acta, 112, 87-101. https://doi.org/10.1016/j.gca.2013.03.005

Ono, S., Keller, N. S., Rouxel, O., \& Alt, J. C. (2012). Sulfur-33 constraints on the origin of secondary pyrite in altered oceanic basement. Geochimica et Cosmochimica Acta, 87, 323-340. https://doi.org/10.1016/j.gca.2012.04.016

Paul, B., Woodhead, J. D., Hergt, J., Danyushevsky, L., Kunihiro, T., \& Nakamura, E. (2011). Melt inclusion Pb-isotope analysis by LA-MCICPMS: Assessment of analytical performance and application to OIB genesis. Chemical Geology, 289(3-4), 210-223. https://doi.org/ 10.1016/j.chemgeo.2011.08.005

Peach, C. L., Mathez, E. A., \& Keays, R. R. (1990). Sulfide melt-silicate melt distribution coefficients for noble metals and other chalcophile elements as deduced from MORB: Implications for partial melting. Geochimica et Cosmochimica Acta, 54(12), 3379-3389. https://doi. org/10.1016/0016-7037(90)90292-S

Pilet, S., Baker, M. B., \& Stolper, E. M. (2008). Metasomatized lithosphere and the origin of alkaline lavas. Science (5878), 320, 916-919.

Roerdink, D. L., Mason, P. R. D., Whitehouse, M. J., \& Brouwer, F. M. (2016). Reworking of atmospheric sulfur in a Paleoarchean hydrothermal system at Londozi, Barberton Greenstone Belt, Swaziland. Precambrian Research, 280, 195-204. https://doi.org/10.1016/j. precamres.2016.05.007

Rouxel, O., Ono, S., Alt, J., Rumble, D., \& Ludden, J. (2008). Sulfur isotope evidence for microbial sulfate reduction in altered oceanic basalts at ODP Site 801. Earth and Planetary Science Letters, 268(1-2), 110-123. https://doi.org/10.1016/j.epsl.2008.01.010

Rouxel, O., Shanks, W. C. III, Bach, W., \& Edwards, K. J. (2008). Integrated Fe-and S-isotope study of seafloor hydrothermal vents at East Pacific Rise 9-10 N. Chemical Geology, 252(3-4), 214-227. https://doi.org/10.1016/j.chemgeo.2008.03.009

Saal, A. E., Hart, S. R., Shimizu, N., Hauri, E. H., \& Layne, G. D. (1998). Pb isotopic variability in melt inclusions from oceanic island basalts, Polynesia. Science (5393), 282, 1481-1484.

Salters, V. J. M., \& Stracke, A. (2004). Composition of the depleted mantle. Geochemistry, Geophysics, Geosystems, 5, Q05B07. https://doi. org/10.1029/2003GC000597

Smit, K. V., Shirey, S. B., Hauri, E. H., \& Stern, R. A. (2019). Sulfur isotopes in diamonds reveal differences in continent construction. Science (6438), 364, 383-385. https://doi.org/10.1126/science.aaw9548 
Sobolev, A. V., Hofmann, A. W., Kuzmin, D. V., Yaxley, G. M., Arndt, N. T., Chung, S.-L., et al. (2007). The amount of recycled crust in sources of mantle-derived melts. Science (5823), 316, 412-417.

Sobolev, A. V., \& Shimizu, N. (1993). Ultra-depleted primary melt included in an olivine from the Mid-Atlantic Ridge. Nature, 363, 151-154. Thirlwall, M. F. (1997). Pb isotopic and elemental evidence for OIB derivation from young HIMU mantle. Chemical Geology, 139(1-4), 51-74. https://doi.org/10.1016/S0009-2541(97)00033-8

Thomassot, E., Cartigny, P., Harris, J. W., Lorand, J. P., Rollion-Bard, C., \& Chaussidon, M. (2009). Metasomatic diamond growth: A multi-isotope study $(13 \mathrm{C}, 15 \mathrm{~N}, 33 \mathrm{~S}, 34 \mathrm{~S})$ of sulphide inclusions and their host diamonds from Jwaneng (Botswana). Earth and Planetary Science Letters, 282(1-4), 79-90. https://doi.org/10.1016/j.epsl.2009.03.001

Thomassot, E., O'Neil, J., Francis, D., Cartigny, P., \& Wing, B. A. (2015). Atmospheric record in the Hadean Eon from multiple sulfur isotope measurements in Nuvvuagittuq Greenstone Belt (Nunavik, Quebec). Proceedings of the National Academy of Sciences, 112(3), 707-712. https://doi.org/10.1073/pnas.1419681112

Veizer, J., Clayton, R. N., \& Hinton, R. W. (1992). Geochemistry of Precambrian carbonates: IV. Early Paleoproterozoic (2.25 \pm 0.25 Ga) seawater. Geochimica et Cosmochimica Acta, 56, 875-885.

Veizer, J., Hoefs, J., Lowe, D. R., \& Thurston, P. C. (1989). Geochemistry of Precambrian carbonates: II. Archean greenstone belts and Archean sea water. Geochimica et Cosmochimica Acta, 53(4), 859-871. https://doi.org/10.1016/0016-7037(89)90031-8

Veizer, J., Plumb, K. A., Clayton, R. N., Hinton, R. W., \& Grotzinger, J. P. (1992). Geochemistry of Precambrian carbonates: V. late Paleoproterozoic seawater. Geochimica et Cosmochimica Acta, 56, 2487-2501.

Weiss, Y., Class, C., Goldstein, S. L., \& Hanyu, T. (2016). Key new pieces of the HIMU puzzle from olivines and diamond inclusions. Nature, 537(7622), 666-670. https://doi.org/10.1038/nature19113

Woodhead, J. D. (1996). Extreme HIMU in an oceanic setting: The geochemistry of Mangaia Island (Polynesia), and temporal evolution of the Cook-Austral hotspot. Journal of Volcanology and Geothermal Research, 72(1-2), 1-19. https://doi.org/10.1016/03770273(96)00002-9

Workman, R. K., \& Hart, S. R. (2005). Major and trace element composition of the depleted MORB mantle (DMM). Earth and Planetary Science Letters, 231(1-2), 53-72. https://doi.org/10.1016/j.epsl.2004.12.005

Yurimoto, H., Kogiso, T., Abe, K., Barsczus, H. G., Utsunomiya, A., \& Maruyama, S. (2004). Lead isotopic compositions in olivine-hosted melt inclusions from HIMU basalts and possible link to sulfide components. Physics of the Earth and Planetary Interiors, 146(1-2), 231-242. https://doi.org/10.1016/j.pepi.2003.08.013 